\title{
Indonesian Novels in the National Newspaper's Response of 2016
}

\author{
Nurhadi Bewe ${ }^{1}$, Kusmarwanti Noe ${ }^{1}$, Dian Swandayani ${ }^{2}$ \\ ${ }^{1}$ Department of Indonesia Language and Literature Education, Yogyakarta State University, Yogyakarta, Indonesia \\ ${ }^{2}$ Department of French Language Education, Yogyakarta State University, Yogyakarta, Indonesia
}

Email address:

nurhadi@uny.ac.id (N. Bewe), kusmarwanti@uny.ac.id (K. Noe),dian_swandajani@uny.ac.id (D. Swandayani)

\section{To cite this article:}

Nurhadi Bewe, Kusmarwanti Noe, Dian Swandayani. Indonesian Novels in the National Newspaper's Response of 2016. International Journal of Literature and Arts. Vol. 6, No. 4, 2018, pp. 63-67. doi: 10.11648/j.ijla.20180604.11

Received: August 5, 2018; Accepted: August 17, 2018; Published: September 12, 2018

\begin{abstract}
This article aims to describe the phenomenon of the development of Indonesian fiction or novel in the response of Indonesian mass media during the year 2016. The phenomenon is derived from a number of reviews of literary works from a number of national newspapers: Kompas, Republika, Koran Tempo, Koran Sindo, and Media Indonesia. Based on the data and analysis of the fiction or novel reviews, there are four literary works that are quite phenomenal, namely: (1) Raden Mandasia si Pencuri Daging Sapi by Yusi Avianto Pareanom, (2) Supernova: Intelegensi Embun Pagi by Dewi Lestari, (3) O by Eka Kurniawan, (4) Tentang Kamu by Tere Liye. The four novels are reviewed at least twice by the national media. The four novels received positive comments from each reviewer. Novel Raden Mandasia si Pencuri Daging Sapi is expert in telling the adventures of his characters in the past, the time before Babad Tanah Jawa. Through the novel Supernova: Intelegensi Embun Pagi, Dewi Lestari is considered the author who has the intelligence to finish the last knitting of the children of his thinking. Tere Liye is a prolific author, at least in 2016 he has published three works of fiction, one of them titled Tentang Kamu. This novel is appreciated as a rich novel. Novel $O$ by Eka Kurniawan not only talks about monkey love or puppy love, but offers more complex things. Here are four novels representing the phenomenon of fiction. Here are four novels from 45 novels that were reviewed during 2016. In addition to these four novels, other novels are quite diverse, both the theme and the genre.
\end{abstract}

Keywords: Novel, Responses, Reviews, Newspaper, Indonesia

\section{Background of the Study}

In the history of Indonesian literature, the last generation is known as the Angkatan 2000 (The 2000 Generation) as has been suggested by Rampan [1]. This generation productively writes about a decade by the year 2000 and a decade after 2000. Thus, it is time that through 2010 it can be assumed that a new literary potency will emerge in Indonesian literary history, perhaps known as Indonesian cyber literature.

The emergence of a new literary potency can actually be seen from the development of comments on literary publications in the mass media, including those found in national newspapers in the form of reviews on literary books. Both conventional newspapers (print) and digital ones (online). Discussion of literature in the form of reviews is not only limited to promotion, but also can be a discursive strategy site. One of them to observe the phenomenon of renewal of the development of literary history of a nation. What appears in a number of literature review, literature has actually passed the selection stage by both the reviewer and the editor.

Thus the selection stage in the preparation of literary history has also been exceeded. To see the discursive phenomena and the compilation of literary history, one of them is by observing what literary works are contained in the mainstream media, namely national newspapers published in Indonesia. This can be started even from the last year, which is in 2018, to pull it back. Especially for this article, will be discussed the works of Indonesian literature reviewed by a number of national newspapers in 2016.

By observing the development of literary works through a number of reviews of Indonesian national newspapers in the early twentieth century, especially in 2016 , it is expected to find things that become the latest Indonesian literary phenomenon. 


\section{The Pathway of Indonesian Literature}

In his book entitled Lintasan Sastra Indonesia Modern 1 (The Path of Modern Indonesian Literature 1), Sumardjo denied that modern Indonesian literature begins with the publication of the Azab dan Sengsara by Merari Siregar in 1921 by Balai Pustaka, a publisher controlled by the Dutch colonial government. Sumardjo declared the works of modern Malay or later known as modern Indonesian literary works have appeared long before the works Balai Pustaka. In the 1870s has been published literary works by Chinese descent, Dutch descent, or natives who have filled the works of modern literature [2].

In summary, the flow of historical development of Indonesian literature is then composed of several generations and / or literary periods consisting of: (1) Embrional Literature, (2) Literature 1920s / Balai Pustaka, (3) Literature 1930s / Pujangga Baru, (4) Angkatan 1945, (5) Literature of Literary Magazines or Angkatan 1966, (6) Literature of 1970/1980's, (7) Angkatan 2000. Until now there has been no history of literary critics or writers who claim that there is new generation of Indonesian literature, although the period actually has enough term for the emergence of a new literary generation.

This is in line with what is expressed by Rampan about the emergence of the latest generation of literature that is Angkatan 2000. This is a book that states the existence of the latest Indonesian literary discussion which contains a number of literary works of writers who take part in the period before and after 2000 [3]. Besides Rampan, Another author who describes the range of Indonesian literary history is Kratz.

In his book entitled Sumber Terpilih Sejarah Sastra Indonesia Abad XX (Selected Source of the History of Indonesian Literature of the XX Century), Kratz describes at a glance the development of the literature of Inodnesia in the twentieth century. This book contains a number of reviews or literary criticisms that discuss the development of Indonesian literature. The first article contained in this book contains "Poetoesan Congres Pemoeda Pemoeda Indonesia" and ends with Putu Wijaya's "Pram" [4]. Rampan's book seems to continue Kratz's book, which ended in the late XX century. The authors tha Rampan included as Angkatan 2000 are authors who had been actively writing at the end of the twentieth century and remained productive until the early twentieth century.

Thus the last period or the most recent in the history of Indonesian literature is the Angkatan 2000 as has been stated by Rampan. Even so, the span of time actually in 2015 or afterwards, it can be assumed that there is a new literary generation taking place. Perhaps the literature of the digital age or the Internet era, where authors in addition to writing conventionally, they also write via e-books and publish it via the internet.

Therefore, the study of the responses of Indonesian national newspapers in response to the latest developments of Indonesian literary works has been an entry point for following and mapping the latest developments in Indonesian literary history. This kind of study can be expanded by observing the development of Indonesian literature written in the form of e-books and the like published on a number of websites or known cyber literature.

\section{Method}

The object of this study is the literature review articles especially to novels in a number of major mass media in Indonesia in 2016. Because of the various limitations and in accordance with the scope of this research study, the object of this study was carried out. The sampling technique used in this study is a purposive sample technique. Research is limited to national mass media, namely: Kompas, Republika, Koran Tempo, Koran Sindo, and Media Indonesia. The book review edition is mostly published on Saturday or Sunday editions. There are 45 novels that were reviewed during 2016

Data collection techniques used in this study was in the form of reading and note-taking techniques. The collected data is then categorized, analyzed, and interpreted. The instrument used to collect data in this study was a data card. The validity and reliability of research data was used by semantic validity techniques and intrarater and interrater techniques. Semantic validity is by analyzing the context of the meaning of text. While for the reliability of the data used intrarater technique that is by reading repeatedly so that the data consistency is obtained. While the interrater technique used in the form of discussions with the members of the researcher.

The collected and categorized data were then analyzed using qualitative descriptive. The data that has been categorized based on the formulation of this problem are then analyzed descriptively so that it can be known the description of the map development of Indonesian literary works, especially the novel.

\section{The Current Indonesian Novels}

\subsection{Review Novels During 2016}

There are 51 writings that deal with literary works in the form of a novel on Indonesian national newspapers in 2016. Of the 51 articles, there are a number of novels covered by more than one article or more than two newspapers. The rest of each novel is discussed only once. The 51 articles cover 45 novels, both original and novel translations (mostly published by Indonesian publishers). Most of the novels are published in 2016.

The novels that appear in the review in January are as follows: Nun, Pada Sebuah Cermin (karya Afifah Afra), 180 (Moh. Cevy Abdullah \& Noorca M. Massardi), Sang Juragan Teh (Hella S. Haase), Maneken (S. J. Munkian), House of Lord (Zhaenal Fanani), Suluk Kiai Cebolek (Ubaidillah Achmad \& Yuliyatun Tajuddin). During February there was a novel that was reviewed, namely Anakku Malaikatku (Kristin Samah).

In March the reviewed novels were: Kalam-kalam Langit 
(Pipit Senja) and Supernova: Supernova: Intelegensi Embun Pagi (Dewi Lestari). In April there were a number of novels reviewed such as: Hujan (Tere Liye), Ada Apa dengan Cinta? (Silvarani), Berpetualang ke 5 Benua (A. Fuadi and Danya), Raden Mandasia si Pencuri Daging Sapi (Yusi Avianto Pareanom).

In May, the novels reviewed include: Impian dari Negeri Sampah (Nadam Dwi Subekti), and a novel entitled O (Eka Kurniawan). In June, it is recorded that there was a review of a novel entitled Tuhan dalam Secangkir Kopi (Denny Siregar). In July it is recorded that there was a review in addition to the novel O (Eka Kurniawan), also for the novel: Keris Setan Kober: Perang Niskala Tanah Jawa (S Trisasongko Hutomo), Kailasa: Jejak Tanah Surga yang Terluka (Yusuf An), Mangalua (Idris Pasaribu).

Furthermore, in August besides a review of the novel Raden Mandasia si Pencuri Daging Sapi (Yusi Avianto Pareanom), there were also reviews of novels: Genduk (Sundari Mardjuki), Istana Para Kuli (Yahya Umar), dan Kerumunan Terakhir (Okky Madasari). During September there were novels: Matahari (Tere Liye) and Odong-odong Dongeng: Kucing dan Anjing (Ipul and Oyas). In October besides a review of the novel Supernova: Intelegensi Embun Pagi (Dewi Lestari), there was also a review of the novel titled Setelah 17 Tahun (Noorca M Massardi). In November, there were two reviews of a novel titled Tentang Kamu (Tere Liye). Also, there was a review of the novel Yusi Avianto Pareanom entitled Raden Mandasia si Pencuri Daging Sapi.

Still in November, there was a review of a novel called Megat (Rida K Liamsi) whose background story takes place in Johor, Malaysia. In December, there were three reviews of the novel: Cintaku di Lembata (Sari Narulita), Kiat Sukses Hancur Lebur (Martin Suryajaya), Ladu (Tosca Santoso). A number of other articles are not specifically from the reviewers but are still related to the discussion of novels or other stories.

During the year 2016, there were also a number of reviews on the translation of foreign works from various countries, both to novels and relatively old as a work of reprint. The translation novels include: The Girl on the Train (Paula Hawkings), Blindness (Jose Samarago), A Man Called Ove (Fredrick Backman), Career of Evil (Robert Galbraith/JK Rowling), What I Talk About When I Talk About Running (Haruki Murakami), Namaku Merah (Orhan Pamuk), Think Like a Freak (Steven D Levitt \& Steven J Dubner), and Rumah Kertas or La Casa de Papel (Carlos Maria Dominguez).

Of the many writers whose novels are reviewed, there are some names that are quite famous in contemporary Indonesian literature. The famous authors include: Noorca M Massardi, Zhaenal Fanani, Dewi Lestari, Tere Liye, A. Fuadi, Yusi Avianto Pareanom, Eka Kurniawan, and Okky Madasari [5-8]. The rest of the names are relatively new appear or less widely known as the main author of Indonesia.

\subsection{Top Indonesian Novels of 2016}

Here is a tabulation of novels that are reviewed twice or more in national newspapers. With the term more than two newspapers, this includes if these novels include the main novels.

Table 1. Top Indonesian Novels Reviewed by National Newspaper in 2016.

\begin{tabular}{|c|c|c|c|c|c|c|c|c|}
\hline \multirow{2}{*}{ No } & \multirow{2}{*}{ Edition } & \multirow{2}{*}{ Media } & \multirow{2}{*}{ Reviewer } & \multirow{2}{*}{$\begin{array}{l}\text { The Title of } \\
\text { Reviews }\end{array}$} & \multicolumn{3}{|l|}{ Books } & \multirow{2}{*}{ Desc } \\
\hline & & & & & Author & Book Titles & Publisher & \\
\hline 1 & 27 Mar & $\begin{array}{l}\text { Media } \\
\text { Indonesia }\end{array}$ & Hera Khaerani & $\begin{array}{l}\text { Rajutan Pamungkas } \\
\text { Dewi Lestari untuk } \\
\text { Supernova }\end{array}$ & Dewi Lestari & $\begin{array}{l}\text { Supernova: } \\
\text { Intelegensi Embun } \\
\text { Pagi }\end{array}$ & $\begin{array}{l}\text { Bentang Pustaka, } \\
\text { Feb } 2016\end{array}$ & novel \\
\hline 2 & $24 \mathrm{Apr}$ & $\begin{array}{l}\text { Media } \\
\text { Indonesia }\end{array}$ & Hera Khaerani & Perjalanan Dendam & $\begin{array}{l}\text { Yusi Avianto } \\
\text { Pareanom }\end{array}$ & $\begin{array}{l}\text { Raden Mandasia } \\
\text { si Pencuri Daging } \\
\text { Sapi }\end{array}$ & $\begin{array}{l}\text { Banana, Mar } \\
2016\end{array}$ & novel \\
\hline 3 & $8 \mathrm{Mei}$ & $\begin{array}{l}\text { Media } \\
\text { Indonesia }\end{array}$ & Hera Khaerani & $\begin{array}{l}\text { Pesta Sudut } \\
\text { Pandang lewat } \\
\text { Novel }\end{array}$ & $\begin{array}{l}\text { Eka } \\
\text { Kurniawan }\end{array}$ & 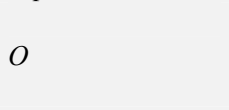 & $\begin{array}{l}\text { Gramedia } \\
\text { Pustaka Utama, } \\
\text { Mar } 2016\end{array}$ & novel \\
\hline 4 & $2 \mathrm{Jul}$ & Kompas & $\begin{array}{l}\text { Tenni } \\
\text { Purwanti }\end{array}$ & $\begin{array}{l}\text { Antitesis Cinta } \\
\text { Monyet }\end{array}$ & $\begin{array}{l}\text { Eka } \\
\text { Kurniawan }\end{array}$ & $O$ & $\begin{array}{l}\text { Gramedia } \\
\text { Pustaka Utama, } \\
\text { Mar } 2016\end{array}$ & novel \\
\hline 5 & 7 Agst & Koran Tempo & $\begin{array}{l}\text { Arif E. } \\
\text { Kurniawan }\end{array}$ & $\begin{array}{l}\text { Dongeng Sebelum } \\
\text { Babad Tanah Jawa }\end{array}$ & $\begin{array}{l}\text { Yusi Avianto } \\
\text { Parianom }\end{array}$ & $\begin{array}{l}\text { Raden Mandasia, } \\
\text { Si Pencuri Daging } \\
\text { Sapi }\end{array}$ & Banana, 2016 & novel \\
\hline 6 & $29 \mathrm{Okt}$ & Kompas & $\begin{array}{l}\text { M Irkham } \\
\text { Abdussalam }\end{array}$ & $\begin{array}{l}\text { Petualangan Mem- } \\
\text { baca Jati Diri }\end{array}$ & Dewi Lestari & $\begin{array}{l}\text { Supernova: } \\
\text { Inteligensi Embun } \\
\text { Pagi }\end{array}$ & $\begin{array}{l}\text { Bentang Pustaka, } \\
\text { Feb } 2016\end{array}$ & novel \\
\hline 7 & $6 \mathrm{Nov}$ & $\begin{array}{l}\text { Media } \\
\text { Indonesia }\end{array}$ & $\begin{array}{l}\text { Abdillah M } \\
\text { Marzuqi }\end{array}$ & $\begin{array}{l}\text { Menelusuri Masa } \\
\text { Lalu Perempuan } \\
\text { Miliuner }\end{array}$ & Tere Liye & Tentang Кати & $\begin{array}{l}\text { Republika, Okt } \\
2016\end{array}$ & novel \\
\hline 8 & $6 \mathrm{Nov}$ & Republika & Gita Amanda & Tentang Kaтu ... & Tere Liye & Tentang Kamu & $\begin{array}{l}\text { Republika, Okt } \\
2016\end{array}$ & novel \\
\hline 9 & $26 \mathrm{Nov}$ & Kompas & Teguh Efendi & $\begin{array}{l}\text { Kembalinya Genre } \\
\text { Silat-Kolosal }\end{array}$ & $\begin{array}{l}\text { Yusi Avianto } \\
\text { Parianom }\end{array}$ & $\begin{array}{l}\text { Raden Mandasia } \\
\text { Si Pencuri Daging } \\
\text { Sapi }\end{array}$ & Banana, 2016 & novel \\
\hline
\end{tabular}


The most widely studied in this study is a novel entitled Raden Mandasia si Pencuri Daging Sapi by Yusi Avianto Pareanom. This novel was published by Banana Publishers in March 2016. The three media covering the novel are Media Indonesia (April 24), Tempo newspaper (August 7), and Kompas (November 26). Each reviewer or review is written by: Hera Khaerani, Arif E. Kurniawan, and Teguh Efendi. The three reviewers write reviews on the novel under the title: "Perjalanan Dendam ", "Dongeng Sebelum Babad Tanah Jawa ", and "Kembalinya Genre Silat-Kolosal ".

Other novels were reviewed twice: Supernova: Intelegensi Embun Pagi (the work of Dewi Lestari), O (by Eka Kurniawan), Tentang Kamu (by Tere Liye), and a Swedish translation novel entitled A Man Called Ove (by Fredrick Backman). The four novels are each published by: Bentang Pustaka (2016), Gramedia Pustaka Utama (March 2016), PT Pustaka Abdi Bangsa or Republika Publishers (October, 2016), and Noura Books (January, 2016). For the purposes of the discussion, only four original Indonesian novels are discussed in this article.

Novel Supernova: Intelegensi Embun Pagi was reviewed by Hera Khaerani in an article entitled "Rajutan Pamungkas Dewi Lestari untuk Supernova" [9]. The second reviewer of the novel by Dewi Lestari was carried out by M Irkham Abdussalam (Kompas, 29 October) in an article entitled "Petualangan Mem baca Jati Diri ".

Eka Kurniawan's novel O was reviewed by Hera Khaerani with the title "Pesta Sudut Pandang lewat Novel" in Media Indonesia (May 8) [10]. The second reviewer of the O novel was written by Tenni Purwanti with an article entitled "Antitesis Cinta Monyet" in Kompas (July 2) [11].

Tentang Kamu byTere Liye is the third novel published in 2016. Before this novel has been published, the novel entitled Matahari and Hujan. Tentang Kamu have been reviewed in Media Indonesia by Abdillah M Marzuqi in his article entitled "Menelusuri Masa Lalu Perempuan"[12]. And also in Republika by Gita Amanda in his article entitled "Tentang Kamu ...." [13]. Both reviews in these two different media were published on November 6th.

In her review, Khaerani stated that the novel Raden Mandasia si Pencuri Daging Sapi by Yusi Avianto Pareanom has nicely borrowed various stories from different times, without losing the reflective context for the present. Although many tell the story of tragedy, the sadness of the victims of war, and battle, the author like to know the right concoction to keep the reader from boredom [14].

Khaerani further stated that the style of writing Yusi A Pareanom in this novel somewhat funny invite laughter. The battle is not simply described as bloodshed, but we are invited into the head of the Sungu Lembu, to his unspoken remnants. The tale told by the back and forth plot is worth thumbs up for the very narrow style of narrative Yusi A Pareanom. The choice of diction is very rich, even the storyline is full of unexpected surprises. The reader is also invited to the story that uses the perspective of the first person of the character Sungu Lembu, the main character of the novel. There are many satires that inspire introspection.

Still from the same reviewer, Khaerani reviewed Dewi Lestari's novel Supernova: Intelegensi Embun Pagi as follows. Everything that has a beginning, there must have an ending. Everything that starts, must also finishes. Dewi Lestari also believed this 15 years ago when she started her novel, Supernova. Ksatria, Puteri dan Bintang Jatuh (2001), Akar (2002), Petir (2004), Partikel (2012), Gelombang (2014) finally got the sweet closure, Intelegensi Embun Pagi (2016). The title has actually been published author who is also the singer since 2002, when published Roots. Dee believes that everything in nature is as simple as any of its manifestations, related to the extraordinary intelligence that drives life. So with the simple morning dew, there is intelligence behind it.

Furthermore, the author of the review in Media Indonesia states that the 705-page book, which from its inception to be the closure to Supernova, synchronizes all the stories from previous books. Instead of merely passing on the previous story, the IEP is a collection of answers from the mystery left in the book. As a consequence, this book is a meeting of old conflicts with new surprises. It proves that he is a well-planned writer and able to execute it as well as parse a seemingly random but highly patterned spider web.

Amanda in a review of the novel Tentang Kamu, questions the setting of the Tere Liye's novel which is based on the City of London, where the main character named Zaman lives. Tere is one of the authors who are reluctant to use overseas settings. Usually he explores various places in the country to be used as a background for his novel. Tere invites readers to trace the life stories of tough women from the most populous fishing villages in the world, Bungin Island, Sumbawa. Armed with Sri's diary (the next character depicted died and left a large amount of inheritance), the reader was invited to reconstruct the life of the woman through the search for Zaman figures [15].

In every chapter of Sri's life, Zaman meets with someone who is still related to Sri. From there relatives who still remember Sri's extraordinary figure recounted Sri's life in that time in detail. Starting from the 1940s when Sri was born on Bungin Island until his death in Paris. Tere also tucked a lot of Indonesian history in every chapter of Sri's life. Through the life story of Sri, readers are invited more closely with important events in Indonesia. Like during the massacre of the kiai during the PKI rebellion, the 1974 Malari rebellion, until the period of the establishment of Monas, Tere explained in his novel through Sri's life story.

The 15th book of Tere Liye with the publisher of the book PT Pustaka Abdi Bangsa or commonly known as Republika Publisher is rich in details. Tere is able to explain everything very well so that readers can enter and enjoy the 33 chapter chapters in the book. Thus one of Amanda's comments in her review.

Purwanti in the Kompas newspaper states after reading this novel, she reflects back on the use of the term monkeys love to call love a moment, playful love, which is not true. Like 
"crocodile" which is a term for men who are unfaithful, even though crocodiles are animals that are most loyal to their partners. After completing this novel, he knew, the novel $\mathrm{O}$ was not as simple as the story of a monkey who wanted to marry the dangdut king [16].

The reader will meet many characters with their own distinct backgrounds. The flow of this novel is built from its characters. There was no figure that was almost in vain, and there were almost no figures without personality, said Eka, which she quoted in her journal about minor characters, which she learned from the works of William Shakespeare. For her, every character, no matter how small, is there because $\mathrm{s} / \mathrm{he}$ is important to be there. And because it is important, no matter how small a character, s/he is still a character who has personality, past, future, interests, and so forth.

Furthermore, Purwanti stated that she also enjoyed when the story jumped up and down like a monkey temporarily telling the story of other characters so that the readers understood the relationship of the characters to one another, also the direct or indirect relationship with $\mathrm{O}$, the monkey. Likewise coarse curses up to the passage of the Holy Qur'an that are inserted into the novel, all in accordance with the portions and indeed important to be there to strengthen the character that is being told.

\section{Conclusion}

Thus the series of reviews of writers in various national newspapers Indonesia in 2016 at least on the four novels that can be considered the main novel, namely the novel of Raden Mandasia si Pencuri Daging Sapi (byYusi Avianto Pareanom), Supernova: Intelegensi Embun Pagi (by Dewi Lestari), Tentang Kamu (by Tere Liye), and a novel entitled $\mathrm{O}$ (by Eka Kurniawan). Here is an example of the 51 articles reviewing 45 new or up-to-date novels in a number of Indonesian national newspapers. These four novels represent the phenomenon of recent Indonesian novel or literary development, especially in 2016.

Of course these four novels are not automatically of better quality than the other novels. There are still a number of other novels that are also discussed by a number of reviewers in the Indonesian mass media during this year whose quality is also not inferior to the four novels. One such novel is Nun, Pada Sebuah Cermin by Afifah Afra (published by Republika Publisher, September 2015) published at the beginning of the year in Republika Newspaper (3 January edition) or Ladu novel by Tosca Santoso (Kaliandra, 2016 on Antropologi Kopi) published at the end of the year in Koran Tempo (December 31 edition) [17, 18].

\section{Acknowledgements}

This article is part of the research result entitled "Indonesian Mass Media Response on Recent Developments of Literature and Implementation of Learning" funded by Institute for Research and Community Service, Universitas Negeri Yogyakarta. For that, we thank you for all the supports.

\section{References}

[1] Rampan, Korrie Layun. 2000. Angkatan 2000 dalam Sastra Indonesia. Jakarta: Grasindo, pp. xxxviii.

[2] Sumardjo, Jakob. 1992. Lintasan Sastra Ind. Modern 1. Bandung: Citra Aditya Bakti.

[3] Rampan, Korrie layun. 2000. Angkatan 2000 dalam Sastra Indonesia. Jakarta: Grasindo, pp: xxv-lv.

[4] Kratz, E. Ulrich. 2000. Sumber Terpilih Sejarah Sastra Indonesia Abad XX. Jakarta: Kepustakaan Populer Gramedia, pp: $\mathrm{xv}$ - xxxix.

[5] Review about of Setelah 17 Tahun novel by Noorca M Massardi has written by Shelbi Asrianti in the article, "Melipur Nestapa 17 Tahun" in Republika, $16^{\text {th }}$ of October edition.

[6] Review about of House of Lord novel by Zhaenal Fanani has written by Irwan Kelana in the article, "Ketika Ka'bah Terancam Musnah" in Republika, $10^{\text {th }}$ of January edition.

[7] Review about of Berpetualang ke 5 Benua novel by A. Fuadi (and Danya) has written by M-2 in the article, "Relaksasi dan Rekreasi" in Media Indonesia, $24^{\text {th }}$ of April edition.

[8] Review about of Kerumunan Terakhir novel by Okky Madasari has written by Akhmad Sekhu in the article, "Menguak Kegagapan Generasi Kekinian" in Kompas, $27^{\text {th }}$ of August edition. The other novels by Dewi Lestari, Tere Liye, Yusi Avianto Pareanom, and Eka Kurniawan will be described in the next references.

[9] Khaerani, Hera. 2016. "Rajutan Pamungkas Dewi Lestari untuk Supernova," in Media Indonesia, $27^{\mathrm{th}}$ of March edition.

[10] Khaerani, Hera. 2016a. "Pesta Sudut Pandang lewat Novel" in Media Indonesia, $8^{\text {th }}$ of May edition.

[11] Purwanti, Tenni. 2016. "Antitesis Cinta Monyet," in Kompas, $2^{\text {nd }}$ of July edition.

[12] Marzuqi, Abdillah M. 2016. "Menelusuri Masa Lalu Perempuan Miliuner" Media Indonesia $6^{\text {th }}$ of November edition.

[13] Amanda, Gita. 2016. “Tentang Kamu ...". in Republika, $6^{\text {th }}$ of November edition.

[14] Khaerani, Hera. 2016b. "Perjalanan Dendam," in Media Indonesia, $24^{\text {th }}$ of April edition.

[15] Amanda, Gita. 2016. "Tentang Kamu ...” dalam Republika, $6^{\text {th }}$ of November edition.

[16] Purwanti, Tenni. 2016. "Antitesis Cinta Monyet," in Kompas, $2^{\text {nd }}$ of July edition. Dangdut is special kind of music from Indonesia represented the lower community.

[17] Review about of Nun, Pada Sebuah Cermin novel by Afifah Afra has written by Adysha C. Ramadani in the article, "Berkaca pada Hidup melalui Nun" in Republika, $3^{\text {th }}$ of January edition.

[18] Review about of Ladu novel by Tosca Santoso has written by Chandra A in the article, "Kisah tentang Kopi dan Pencarian Tuhan" in Koran Tempo, $31^{\text {st }}$ of December edition. 